\title{
Optimization of protein extraction from fish waste using Response Surface Methodology
}

\begin{abstract}
The aim of present study was to optimize protein extraction from Fish Waste (FW), sardine (Sardina pilchardus) using enzymatic method. In this study, enzymatic method involved two combinations of enzymes which were alcalase and protamex. Response Surface Methodology (RSM) was used to study the effect of independent variables, namely temperature $\left(35-55^{\circ} \mathrm{C}\right)$, rotation speed (100-300 $\mathrm{rpm})$, time (60-1440 min) and enzyme:substrate ratio (0.5-1.5) on protein extraction from FW. From RSM-generated model, the optimum conditions for extraction of protein from $\mathrm{FW}$ were identified to be at temperature $35^{\circ} \mathrm{C}$ in 1429 min reaction time, with rotation speed of $171 \mathrm{rpm}$ and enzyme:substrate ratio of 1.50 . At the optimum conditions, predicted protein yield in the extraction process was $80.75 \mathrm{mg} \mathrm{mL}-1$.
\end{abstract}

Keyword: Enzymatic method; Fish waste; Response Surface Methodology; Sardine pilchardus 